\title{
Experimental Evaluation and Empirical Modelling of Cross-flow Microfiltration for Solids and Ash Removal from Fast Pyrolysis Bio-oil
}

\section{Supplementary Material}

\section{Design of Experimental Cross-flow Microfiltration System}

To study the microfiltration profiles of fast pyrolysis bio-oils for suspended char particulate (solids) and ash removal, a bench scale cross-flow microfiltration system was designed and assembled at CanmetENERGY-Ottawa. The system was designed to produce as much as $1 \mathrm{~L} \mathrm{~h}^{-1}(\mathrm{LPH})$ of bio-oil permeate. Over the course of the work, the cross-flow microfiltration system was modified in response to lessons learned and to incorporate process improvements to better achieve research objectives. After the proofof-concept stage, the system was modified to create the MRK II version of the system. The most significant changes included new, larger microfiltration cells with larger active filtration areas (discussed further below). The major experimental objective of the MRK II unit was to explore the impact of operating parameters on the flux profiles for FPBO cross-flow microfiltration. An image of the MRK II version of the system is found in Figure A. 1.

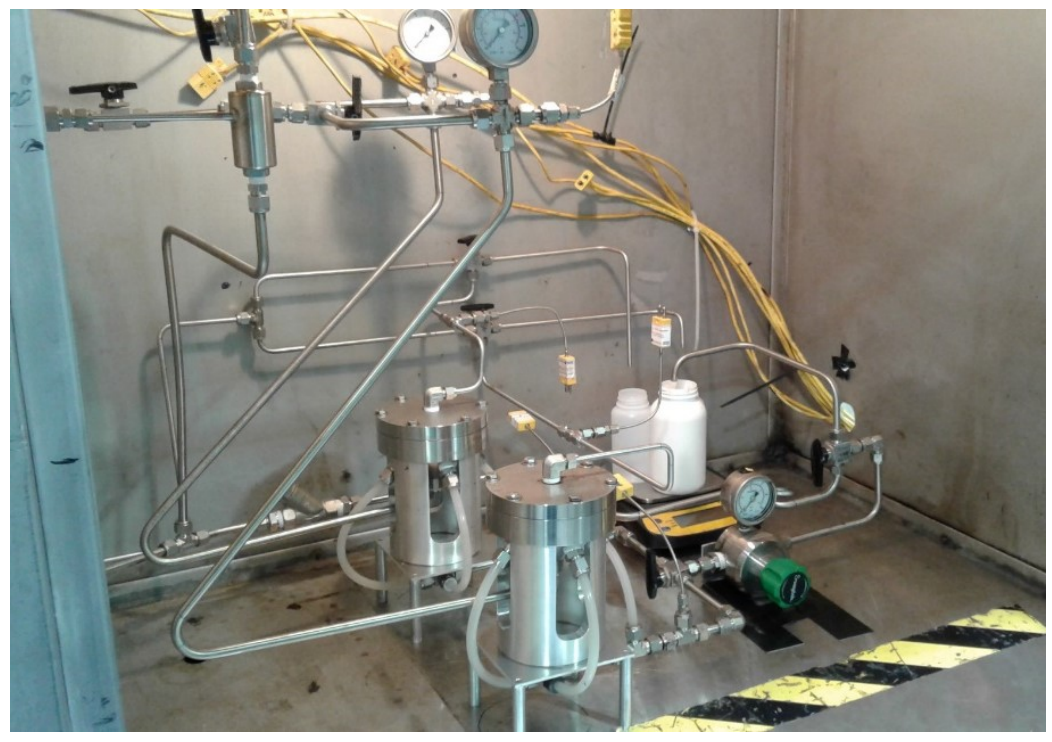

Figure A. 1: Picture of experimental cross-flow FPBO microfiltration system MRK II (2017)

The filtration cells used in this work were designed and constructed at CanmetENERGY-Ottawa. Design features of the cells include the inversion of the feed/permeate such that the feed was introduced from the bottom of the active filtration surface (typically the permeate is at the bottom of the cell, and the 
retentate at the top), while the internal volume on the feed side of the cell was increased, and multiple inlet ports for fluid injection were added. The main considerations for these design changes included the intention to facilitate the removal of the accumulated fouling on the active filtration cell, as well as increasing the shear force acting on the fouling layer. A drawing and some additional images of microfiltration cell 3 are included below.

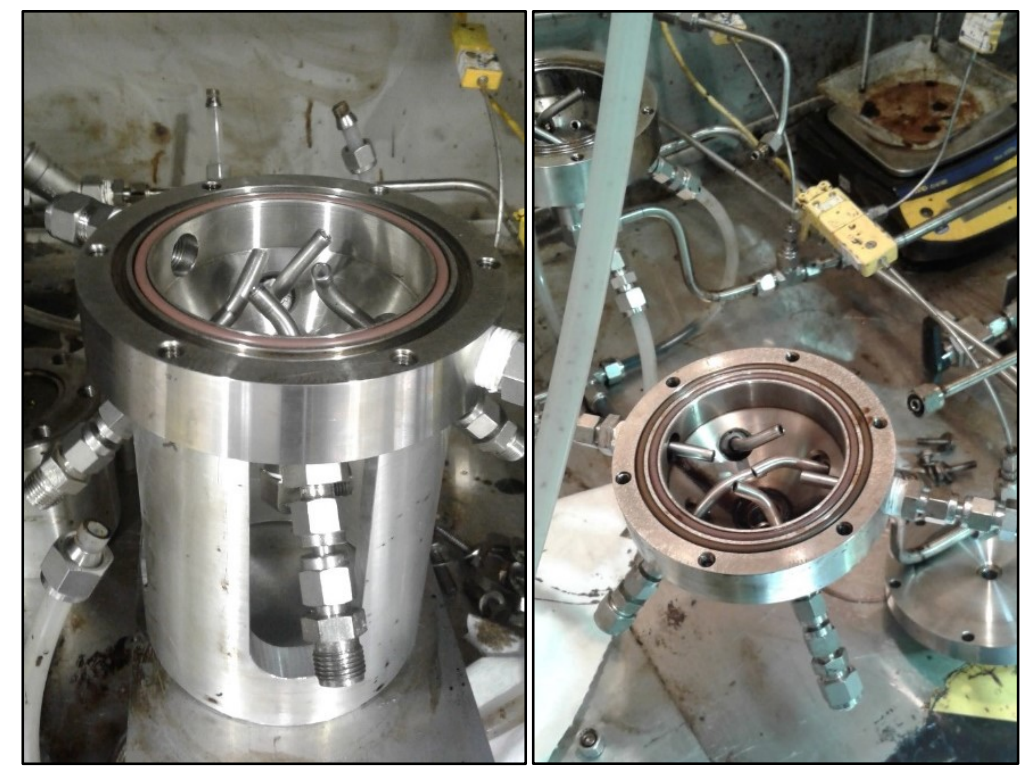

Figure A. 2: Side view of different flow configurations for prototype filtration cell used in bio-oil microfiltration studies with the MRK II and MRK III experimental system

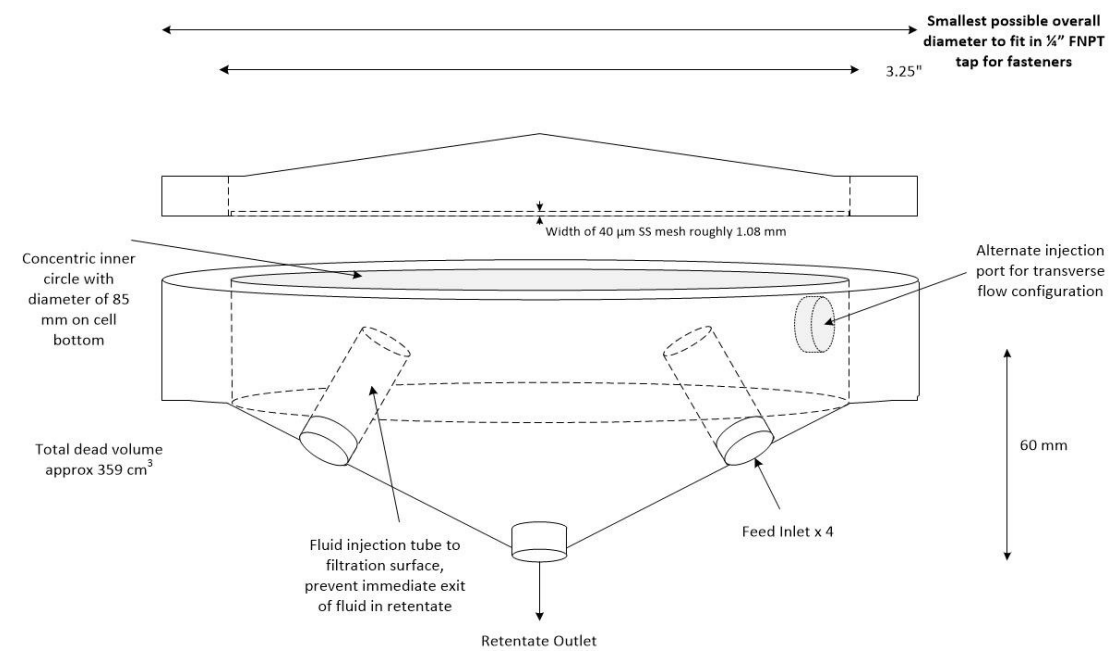

Figure A. 3: Simplified drawing of customized filtration cell fabricated at CanmetENERGY-Ottawa for biooil microfiltration studies 


\section{Properties of Bio-oils used in Microfiltration Study}

See below a summary of the fast pyrolysis bio-oils used for microfiltration study. More information related to the biomass feedstocks converted to produce the FPBO is located in Appendix A in the following reference [1].

Table A. 1 Summary of production information and properties of FPBOs used for microfiltration studies

\begin{tabular}{|c|c|c|c|c|c|}
\hline $\begin{array}{c}\text { Internal } \\
\text { Numerical } \\
\text { ID } \\
\end{array}$ & Original Feedstock & $\begin{array}{c}\text { Approximate } \\
\text { Reactor } \\
\text { Temperature }\left({ }^{\circ} \mathrm{C}\right)^{\mathrm{b}} \\
\end{array}$ & $\begin{array}{l}\text { Age at Use } \\
\text { (months) }\end{array}$ & $\begin{array}{l}\text { Solids Content } \\
(w t \%)^{b}\end{array}$ & $\begin{array}{l}\text { Ash Content } \\
(w t \%)^{b}\end{array}$ \\
\hline 1 & Coastal Hog Fuel & 480 & 7 & & 0.167 \\
\hline 2 & $\begin{array}{l}\text { Hardwood Sawdust } \\
\text { Flooring Residue }\end{array}$ & 480 & 5 & 0.3 & 0.033 \\
\hline 3 & $\begin{array}{l}\text { Hardwood Sawdust } \\
\text { Flooring Residue }\end{array}$ & 480 & 5 & 2.27 & 0.092 \\
\hline 4 & Mill Hog Fuel & 400 & 14 & $0.36-0.41$ & 0.364 \\
\hline 5 & $\begin{array}{l}\text { Hardwood Harvest Residue } \\
\text { (Forest Slash) }\end{array}$ & 480 & 16 & $0.5-0.64$ & \\
\hline $6^{a}$ & Unknown origin feedstock & $\begin{array}{l}\text { Unknown operating } \\
\text { conditions }\end{array}$ & $<5$ & $0.03-0.07$ & 0.045 \\
\hline 7 & $\begin{array}{l}\text { Hardwood Sawdust } \\
\text { Flooring Residue }\end{array}$ & $460-480$ & $2-12$ & 0.45 & 0.13 \\
\hline 8 & $\begin{array}{l}\text { Hardwood Harvest Residue } \\
\text { (Forest Slash) }\end{array}$ & 480 & $<1$ & $0.12-0.55$ & $0.135-0.14$ \\
\hline 9 & $\begin{array}{l}\text { Softwood Sawdust } \\
\text { (Sawmill Residue) }\end{array}$ & 480 & 48 & 0.41 & 0.154 \\
\hline 10 & $\begin{array}{l}\text { Hardwood Sawdust } \\
\text { Flooring Residue }\end{array}$ & $400-480$ & 36 & $0.37-0.48$ & \\
\hline 11 & $\begin{array}{l}\text { Hardwood Sawdust } \\
\text { Flooring Residue }\end{array}$ & $400-480$ & $2-36$ & $0.35-0.63$ & 0.191 \\
\hline
\end{tabular}

${ }^{a}$ obtained from external supplier, thus the feedstock and operating conditions are unknown; ${ }^{b}$ When a range is provided, this indicates that multiple bio-oils under the same feedstock or production conditions were used with the range of properties included

\section{Properties of Filtration Media}

The properties of the various filtration media that were used over the course of the bio-oil microfiltration experiments are listed in Table A. 2 for reference, along with the estimated membrane resistance as calculated by a derivative of the Kozeny-Carmen equation for laminar flow through a packed bed [2] as shown below. 
Table A. 2: Specifications of filtration media used in experimental testing for bio-oil microfiltration

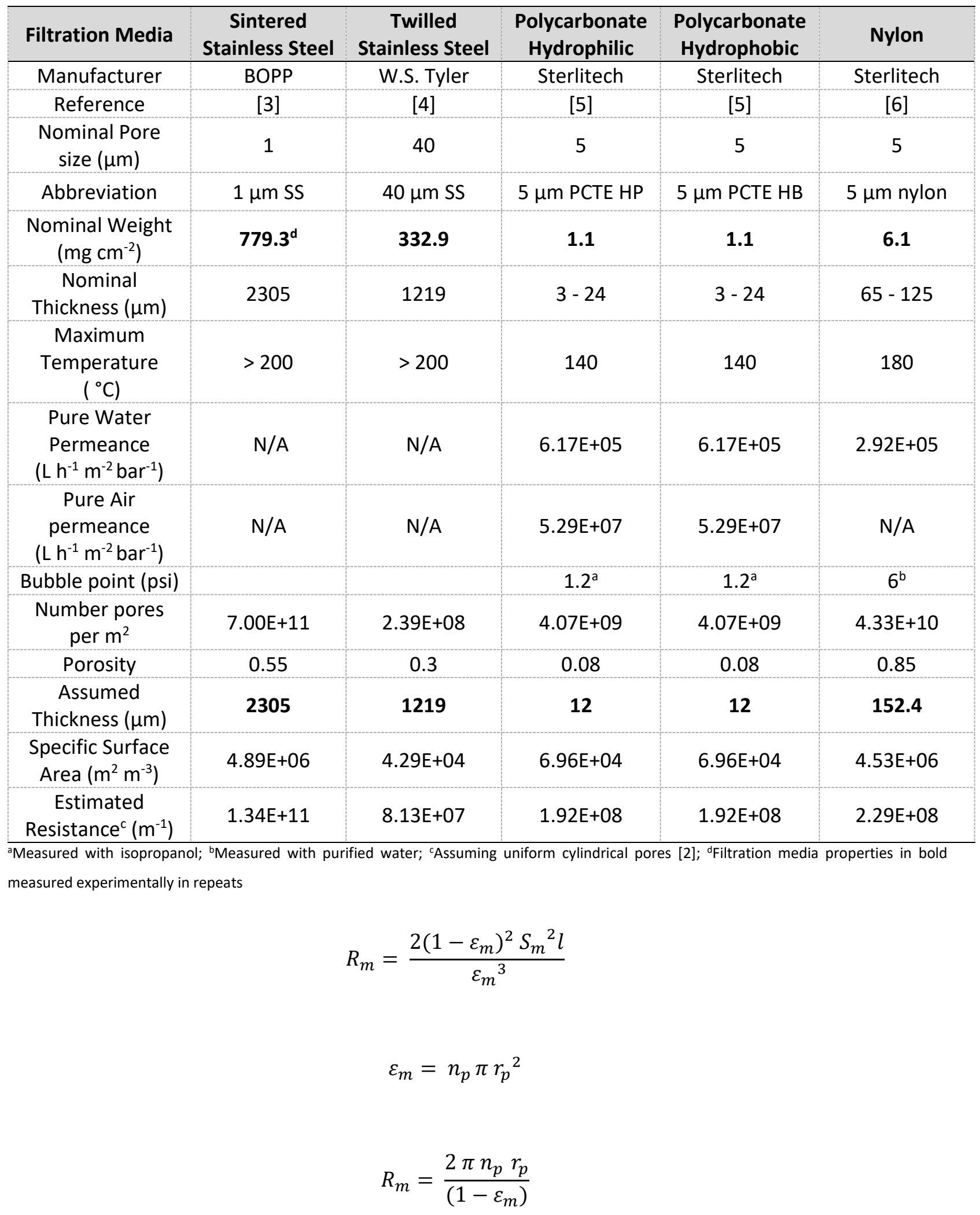


where $\varepsilon_{m}$ is the porosity of the membrane, $S_{m}$ is the specific surface area, $n_{p}$ is the number of pores per unit area and $\mathrm{I}$ is the membrane thickness

Use of diascopic bright field microscopy to assess solids removal

During early experimental testing of cross-flow microfiltration with fast pyrolysis bio-oils, microscope imaging was used as a qualitative indicator for solids removal. Similar procedures were followed in existing literature on the subject [7]. Some select microscope images are included below to visually demonstrate the removal of suspended char particles in FPBO from cross-flow microfiltration. A Nikon ECLIPSE 50i POL diascopic bright-field microscopy unit was used to capture the images below.
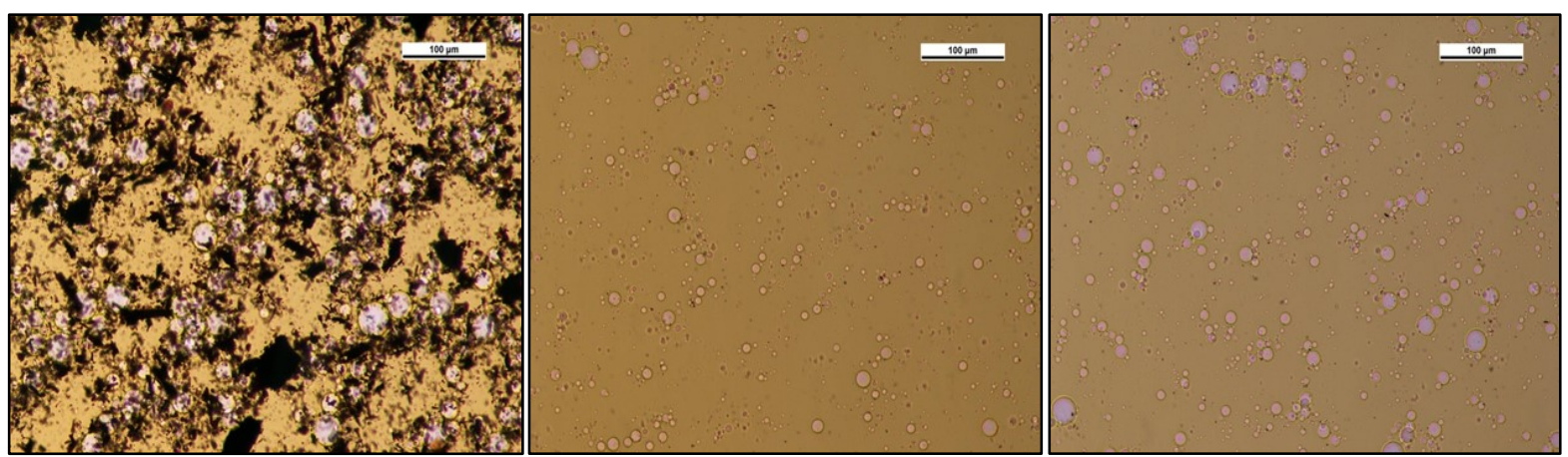

Figure A. 4: Microscope images (200x magnification) of a $2.3 \mathrm{wt} \%$ solids bio-oil (left) feed, with the permeate using a $5 \mu \mathrm{m}$ hydrophilic polycarbonate membrane (middle) and a $5 \mu \mathrm{m}$ hydrophobic polycarbonate membrane (right)

An important note here is that what appears to be air bubbles in the images above is actually emulsified droplets of the quench fluid that is used during condensation of the pyrolysis vapours in the pilot scale fast pyrolysis unit at CanmetENERGY-Ottawa.

A few procedural steps were followed to capture the microscope images:

i. Representatively sub-sample the bio-oil sample into a vial (in this case, $30 \mathrm{~mL}$ vials were used)

ii. Clean the microscope slides and cover slips with lint-free wipes. Use solvent to clean if necessary.

iii. Prior to sampling, ensure the aliquot of FPBO is well-mixed such that the solids may be assumed as evenly dispersed.

iv. As soon as possible after mixing, use a clean pipette to remove a small volume (1-5 $\mathrm{mL}$ ) of the biooil. It is recommended to remove the sample from the middle section of the vial, and not the top/bottom. 
v. Prior to depositing a drop of the bio-oil on the microscope slide, allow 1-2 drops of the sample to pass through the pipette to avoid any air bubbles. Once this is ensured, place 1-2 drops of the biooil on the microscope slide.

vi. Place the cover slip on the bio-oil sample. This is best done by applying the slip at approximately a $30^{\circ}$ angle from the microscope slide plane, and done very slowly.

vii. Depending on the kinematic viscosity of the bio-oil, viscosity reduction may be required prior to sampling using a pipette. This may be done by adding a low viscosity diluent, or pre-heating the sample to appropriate temperatures $\left(40-60^{\circ} \mathrm{C}\right)$.

In addition to microscope images of the bio-oils before and after filtration, some microscope imaging was performed on the filtration media in an attempt to better understand the fouling that was occurring. An image of a PTFE membrane before/after bio-oil microfiltration is demonstrated below for reference.
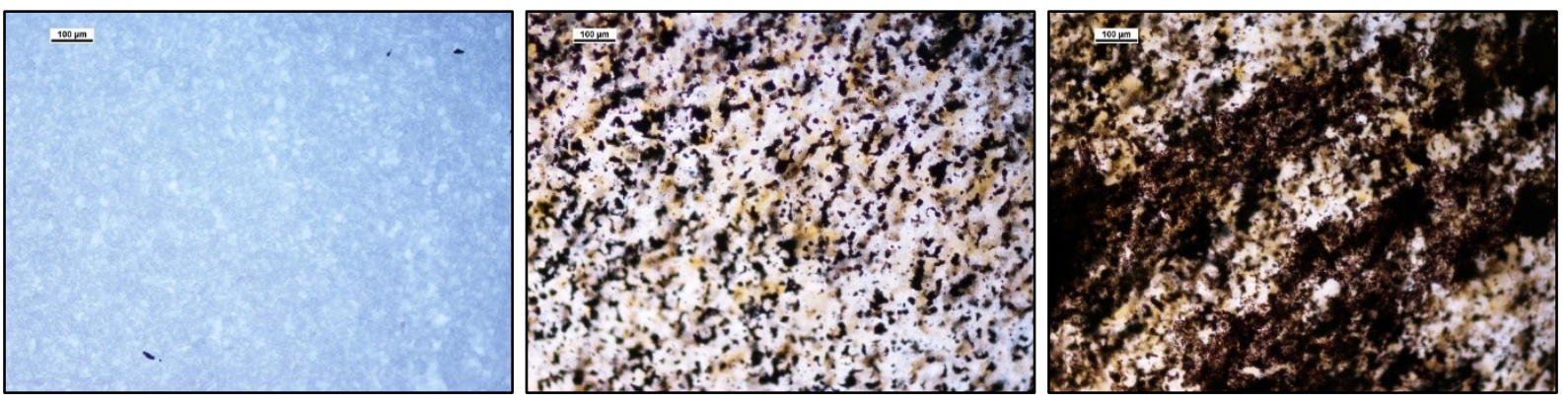

Figure A. 5: Optical microscope image of $5 \mu \mathrm{m}$ PTFE membrane at 100x magnification before (left) and after bio-oil microfiltration (middle and right) showing different levels of fouling on surface of membrane

\section{Properties of feed and permeate samples in FPBO cross-flow microfiltration}

In some instances, the physicochemical properties of the produced low-solids permeate samples were compared to the unfiltered bio-oil. Previous literature has found that the chemical composition of the biooil was largely unchanged, with the exception of hydroxyacetaldehyde doubling after microfiltration, although no explanation for this phenomenon was offered [7]. Furthermore, it was found that there were small increases in the water-soluble fraction (and necessarily small reductions in the water-insoluble fraction) of bio-oil after microfiltration. It was believed that this was due to the removal of the char particles, which are hydrophobic in nature. A summary of relevant physicochemical properties of FPBO before/after microfiltration is shown in Table A. 3. Note that chemical analysis of the FPBO was not performed in this work. 
Generally, the low-solids permeate bio-oil displayed marginal increases in water content and density, while also demonstrating marginal reductions in kinematic viscosity relative to the unfiltered bio-oil. This result is most likely linked to the physical removal of the char particles. It is also interesting to note that the density increases after microfiltration, which validates that the density of the suspended char particles is lower than that of the fast pyrolysis bio-oil. However, it is important to note that the changes in these properties are quite small, and thus is may be applicable to assumed that the physicochemical properties of filtered bio-oil (with the exception of solids and ash) are quite comparable to that of unfiltered bio-oil. This result could theoretically change depending on the filtration media and pore size used, as the rejection of individual components in bio-oil could significantly change the bulk properties of the lowsolids permeate. 
Table A. 3: Summary of select physicochemical properties of fast pyrolysis bio-oils before and after cross-flow microfiltration

\begin{tabular}{|c|c|c|c|c|c|c|c|c|c|c|c|c|c|c|c|c|}
\hline \multirow{3}{*}{$\begin{array}{c}\text { Bio-Oil Used }^{\mathbf{b}} \\
6\end{array}$} & \multirow{2}{*}{$\begin{array}{c}\text { Filter Type } \\
\text { Stream } \\
\end{array}$} & \multirow{3}{*}{$\begin{array}{c}\text { Fluid } \\
\begin{array}{c}\text { Temperature } \\
\left({ }^{\circ} \mathrm{C}\right)\end{array} \\
\end{array}$} & \multirow{3}{*}{$\begin{array}{c}\text { Average } \\
\text { TMP (bar) } \\
\\
0.69\end{array}$} & \multirow{3}{*}{$\begin{array}{c}\begin{array}{c}\text { Solvent } \\
\text { Concentration } \\
\text { in Feed (wt\%) }\end{array} \\
20\end{array}$} & \multicolumn{2}{|c|}{$\begin{array}{l}\text { Solids Content } \\
\text { (wt\%) }\end{array}$} & \multicolumn{2}{|c|}{$\begin{array}{l}\text { Ash Content } \\
\text { (wt\%) }\end{array}$} & \multicolumn{2}{|c|}{$\begin{array}{l}\text { Water Content } \\
\text { (wt\%) }\end{array}$} & \multicolumn{2}{|c|}{$\begin{array}{c}\text { Kinematic } \\
\text { viscosity } \\
\text { @operating } \\
\text { temperature } \\
\left(\mathrm{mm}^{2} \mathrm{~s}^{-1}\right) \\
\end{array}$} & \multicolumn{2}{|c|}{$\begin{array}{c}\text { Heating } \\
\text { Value (MJ kg- } \\
\text { 1) }\end{array}$} & \multicolumn{2}{|c|}{$\begin{array}{l}\text { Density } \\
\left(\mathrm{kg} \mathrm{m}^{-3}\right)\end{array}$} \\
\hline & & & & & $\mathbf{F}$ & $\mathbf{P}$ & $\mathbf{F}$ & $\mathbf{P}$ & $\mathbf{F}$ & $\mathbf{P}$ & $F$ & $\mathbf{P}$ & $F$ & $\mathbf{P}$ & $\mathbf{F}$ & $\mathbf{P}$ \\
\hline & 5-6 $\mu \mathrm{m}$ PTFE & & & & 0.14 & 0.12 & 0.018 & 0.014 & & & 13.85 & 13.21 & & & & \\
\hline 6 & 5-6 $\mu \mathrm{m}$ PTFE & 40 & 0.69 & & 0.05 & 0.13 & 0.014 & 0.016 & & & 34.15 & 33.88 & & & & \\
\hline 2 & 5-6 $\mu \mathrm{m}$ PTFE & 40 & 1.72 & & 0.4 & 0.09 & 0.078 & 0.041 & & & 26.57 & 24.62 & & & & \\
\hline 2 & $40 \mu \mathrm{m} \mathrm{SS}$ & 40 & 1.72 & & 0.4 & 0.11 & 0.078 & 0.031 & & & & & & & & \\
\hline 2 & $5-6 \mu \mathrm{m}$ PTFE & 40 & 1.03 & 20 & 0.27 & 0.08 & 0.067 & 0.001 & & & & & & & & \\
\hline 2 & $40 \mu \mathrm{m} \mathrm{SS}$ & 40 & 1.03 & 20 & 0.27 & 0.11 & 0.067 & 0.012 & & & 11.9 & 11.02 & & & & \\
\hline 2 & $40 \mu \mathrm{m} \mathrm{SS}$ & 40 & 0.69 & 20 & 0.25 & 0.22 & 0.059 & 0.057 & & & 13.45 & 13.41 & & & & \\
\hline 2 & $40 \mu \mathrm{m} \mathrm{SS}$ & 40 & 0.69 & & 0.29 & 0.1 & 0.068 & 0.054 & & & & & & & & \\
\hline 2 & $40 \mu \mathrm{m} \mathrm{SS}$ & 40 & 0.69 & & 0.29 & 0.2 & 0.068 & 0.06 & 17.8 & 18.0 & 28.05 & 27.83 & 19.78 & 19.26 & & \\
\hline 2 & $5 \mu \mathrm{m}$ HP PCTE & 40 & 3.10 & & 0.27 & 0.07 & 0.065 & 0.044 & 16.8 & 17.0 & 26.12 & 25.66 & 19.81 & 18.81 & 1185 & 1204 \\
\hline 2 & $5 \mu \mathrm{m}$ HB PCTE & 40 & 3.10 & & 0.27 & 0.05 & & & 16.8 & 17.3 & 26.12 & 26.05 & 19.81 & 18.72 & 1185 & 1205 \\
\hline 2 & $5 \mu \mathrm{m}$ HP PCTE & 40 & 3.10 & & 0.25 & 0.06 & 0.061 & 0.048 & 16.8 & 17.2 & 23.83 & 22.76 & 19.45 & 18.29 & 1182 & 1201 \\
\hline 1 & $5 \mu \mathrm{m}$ HP PCTE & 40 & 3.10 & 20 & 0.16 & 0.05 & 0.171 & 0.187 & & & 9.0 & 8.9 & & & 1149 & 1147 \\
\hline 1 & $5 \mu \mathrm{m} \mathrm{HB}$ PCTE & 40 & 3.10 & 20 & & 0.08 & & 0.166 & & & & 9.0 & & & & 1153 \\
\hline 3 & $5 \mu \mathrm{m}$ HP PCTE & 40 & 3.10 & & 2.3 & 0.04 & 0.119 & 0.046 & & & 24.35 & 19.84 & & & 1156 & 1202 \\
\hline 2 & $40 \mu \mathrm{m} S \mathrm{~S}$ & 40 & 3.10 & & 0.3 & 0.07 & 0.033 & 0.021 & & & & & & & 1188 & 1204 \\
\hline 2 & $5 \mu \mathrm{m}$ HB PCTE & 40 & 3.10 & & 0.3 & 0.05 & 0.033 & 0.018 & & & & & & & 1188 & 1197 \\
\hline 3 & $40 \mu \mathrm{m} \mathrm{SS}$ & 40 & 3.10 & & 2.27 & 0.03 & 0.092 & 0.051 & & & & & & & 1153 & 1198 \\
\hline 3 & $5 \mu \mathrm{m}$ HB PCTE & 40 & 3.10 & & 2.27 & 0.04 & 0.092 & 0.049 & & & & & & & 1153 & 1188 \\
\hline 2 & $40 \mu \mathrm{m} \mathrm{SS}$ & 40 & 3.10 & & 0.3 & 0.07 & 0.033 & 0.021 & & & 19.4 & & & & & \\
\hline 2 & $5 \mu \mathrm{m}$ PCTE HB & 40 & 3.10 & & 0.3 & 0.05 & 0.033 & 0.018 & & & 19.4 & & & & & \\
\hline 3 & $40 \mu \mathrm{m} \mathrm{SS}$ & 40 & 3.10 & & 2.27 & 0.03 & 0.092 & 0.051 & & & 23.1 & & & & & \\
\hline 3 & $5 \mu \mathrm{m}$ PCTE HB & 40 & 3.10 & & 2.27 & 0.04 & 0.092 & 0.049 & & & 23.1 & & & & & \\
\hline 10 & $40 \mu \mathrm{m} \mathrm{SS}$ & 40 & 0.34 & & 0.4 & 0.01 & & & & & 16.4 & 15.9 & & & & \\
\hline 4 & $40 \mu \mathrm{m} \mathrm{SS}$ & 40 & 0.34 & 20 & 0.36 & 0.13 & 0.364 & 0.313 & & & 6.6 & 6.6 & & & & \\
\hline 4 & $5 \mu \mathrm{m}$ nylon & 40 & 0.34 & 20 & 0.41 & 0.04 & 0.364 & 0.332 & & & 6.7 & & & & & \\
\hline 4 & $20 \mu \mathrm{m}$ nylon & 40 & 0.34 & 20 & 0.38 & 0.05 & & 0.391 & & & 6.8 & & & & & \\
\hline 5 & $40 \mu \mathrm{m} \mathrm{SS}$ & 40 & 0.34 & & 0.64 & 0.12 & & & 16.2 & 16.1 & 28.5 & & & & & \\
\hline 5 & $40 \mu \mathrm{m}$ SS & 40 & 0.69 & & 0.54 & 0.07 & & & 14.3 & 14.5 & 21.5 & & & & & \\
\hline
\end{tabular}




\begin{tabular}{|c|c|c|c|c|c|c|c|c|c|c|c|c|c|c|c|c|}
\hline \multirow{3}{*}{$\begin{array}{c}\text { Bio-Oil Used }{ }^{\mathbf{b}} \\
8\end{array}$} & \multirow{2}{*}{$\begin{array}{l}\text { Filter Type } \\
\text { Strean }\end{array}$} & \multirow{3}{*}{$\begin{array}{c}\begin{array}{c}\text { Fluid } \\
\text { Temperature } \\
\left({ }^{\circ} \mathrm{C}\right)\end{array} \\
40\end{array}$} & \multirow{3}{*}{$\begin{array}{c}\text { Average } \\
\text { TMP (bar) } \\
\\
0.34 \\
\end{array}$} & \multirow{3}{*}{$\begin{array}{c}\text { Solvent } \\
\text { Concentration } \\
\text { in Feed (wt\%) }\end{array}$} & \multicolumn{2}{|c|}{$\begin{array}{c}\text { Solids Content } \\
\text { (wt\%) }\end{array}$} & \multicolumn{2}{|c|}{$\begin{array}{c}\text { Ash Content } \\
\text { (wt\%) }\end{array}$} & \multicolumn{2}{|c|}{$\begin{array}{l}\text { Water Content } \\
\text { (wt\%) }\end{array}$} & \multicolumn{2}{|c|}{$\begin{array}{c}\text { Kinematic } \\
\text { viscosity } \\
\text { @operating } \\
\text { temperature } \\
\left(\mathrm{mm}^{2} \mathrm{~s}^{-1}\right)\end{array}$} & \multicolumn{2}{|c|}{$\begin{array}{c}\text { Heating } \\
\text { Value (MJ kg- } \\
\text { 1) }\end{array}$} & \multicolumn{2}{|c|}{$\begin{array}{l}\text { Density } \\
\left(\mathrm{kg} \mathrm{m}^{-3}\right)\end{array}$} \\
\hline & & & & & $\mathbf{F}$ & $\mathbf{P}$ & $\mathbf{F}$ & $\mathbf{P}$ & $\mathbf{F}$ & $\mathbf{P}$ & $\mathbf{F}$ & $\mathbf{P}$ & $\mathbf{F}$ & $\mathbf{P}$ & $\mathbf{F}$ & $\mathbf{P}$ \\
\hline & $5 \mu \mathrm{m}$ nylon & & & & 0.44 & 0.06 & 0.139 & 0.106 & 24.4 & & 20.3 & & & & & \\
\hline 8 & $5 \mu \mathrm{m}$ nylon & 45 & 0.34 & & 0.12 & 0.01 & 0.135 & 0.142 & & & 19.9 & & & & & \\
\hline 8 & $40 \mu \mathrm{m} \mathrm{SS}$ & 45 & 0.34 & & 0.12 & 0.01 & 0.135 & 0.138 & & & 19.9 & & & & & \\
\hline 6 & $5 \mu \mathrm{m}$ nylon & 47.5 & 0.34 & & 0.05 & 0.02 & 0.045 & 0.048 & 23.5 & & 16.8 & & & & & \\
\hline 6 & $5 \mu \mathrm{m}$ PCTE HB & 47.5 & 0.34 & & 0.05 & 0.07 & & 0.048 & & & 16.8 & & & & & \\
\hline 5 & $5 \mu \mathrm{m}$ nylon & 40 & 0.69 & & 0.54 & 0.02 & & & 14.3 & 14.6 & 21.5 & & & & & \\
\hline 5 & $40 \mu \mathrm{m} \mathrm{SS}$ & 40 & 0.48 & & 0.5 & 0.05 & & & 13.2 & 13.5 & 18.8 & & & & & \\
\hline 5 & $5 \mu \mathrm{m}$ nylon & 40 & 0.69 & & 0.5 & 0.02 & & & 13.2 & 13.4 & 18.8 & & & & & \\
\hline 11 & $5 \mu \mathrm{m}$ nylon & 50 & 0.69 & & 0.43 & 0.03 & & 0.02 & & & 28.0 & & & & & \\
\hline 11 & $40 \mu \mathrm{m} \mathrm{SS}$ & 50 & 0.69 & & 0.43 & 0.17 & & 0.18 & & & 28.0 & & & & & \\
\hline 11 & $5 \mu \mathrm{m}$ nylon & 50 & 0.34 & & 0.41 & 0.01 & 0.191 & 0.167 & & & 28.0 & & & & & \\
\hline 9 & $1 \mu \mathrm{m} \mathrm{SS}$ & 50 & 0.59 & & 0.41 & 0.01 & 0.154 & 0.119 & 25.2 & 23.8 & 13.1 & & & & & \\
\hline 9 & $40 \mu \mathrm{m} \mathrm{SS}$ & 50 & 0.59 & & 0.41 & 0.06 & 0.154 & 0.124 & 25.2 & 24.1 & 13.1 & & & & & \\
\hline 11 & $1 \mu \mathrm{m} \mathrm{SS}$ & 51.4 & 0.69 & & 0.69 & 0.06 & 0.122 & 0.091 & 20.7 & 23 & 21.0 & 20.0 & & & & \\
\hline 11 & $1 \mu \mathrm{m} \mathrm{SS}$ & 52.1 & 0.69 & & 0.08 & 0.08 & 0.107 & 0.115 & 21.6 & 21.4 & 19.4 & 21.4 & & & & \\
\hline
\end{tabular}




\section{Additional References}

[1] D. Mazerolle, Experimental Evaluation of Solids and Ash Removal Pathways of Fast Pyrolysis Biooils, University of Ottawa, 2019. https://ruor.uottawa.ca/handle/10393/39883?mode=full.

[2] W.S.W. Ho, K.K. Sirkar, Membrane Handbook, Springer US, 1992.

[3] BOPP, Precision woven stainless steel filter mesh, (2012). http://www.bopp.ch/Bopp2012/media/boppLibrary/DownloadCenter/English/brochures/Bopp_FI_Metallfiltergewebe-e_2012.pdf.

[4] W.S Tyler, Wire cloth handbook, (2018).

[5] Sterlitech, POLYCARBONATE TRACK ETCH (PCTE) MEMBRANE FILTERS, (2016) 1.

[6] Sterlitech, Nylon Membrane Filters, (2018) 2. http://www.sterlitech.com/filters/membrane-discfilters/nylon-membranes.html.

[7] A. Javaid, T. Ryan, G. Berg, X. Pan, T. Vispute, S.R. Bhatia, G.W. Huber, D.M. Ford, Removal of char particles from fast pyrolysis bio-oil by microfiltration, J. Memb. Sci. 363 (2010) 120-127. doi:10.1016/j.memsci.2010.07.021. 